\title{
Eksistensi \\ Pendidikan Anak Usia Dini (PAUD) Terpadu
}

\author{
Asmariani \\ Dosen Manajemen Pendidikan Agama Islam \\ Fakultas Ilmu Agama Islam \\ Universitas Islam Indragiri (FIAI - UNISI) Tembilahan
}

\begin{abstract}
Abstraks
PAUD adalah upaya pembinaan yang ditujukan kepada anak sejak lahir sampai dengan usia enam tahun yang dilakukan melalui pemberian rangsangan pendidikan untuk membantu pertumbuhan dan perkembanagan jasmani dan rohani agar anak memiliki kesiapan dalam memasuki pendidikan lebih lanjut. PembinaanPAUD perlu dilaksanakan secara terpadu dan terkoordinasi, agar kemampuan anak dapat berkembang sesuai dengan usianya.Program PAUD Terpaduadalah program layanan pendidikan bagi anak usia dini yang menyelenggarakan lebih dari satu program PAUD (TK, KB, TPA, SPS) dalam pembinaan, penyelenggaraan dan pengelolaannya dilakukan secara terpadu atau terkoordinasi. Eksistensi PAUD terpadu merupakan sebuah jawaban permasalahan Pendidikan pada suatu komunitas di daerah maka dibutuhkan kerja ekstra dalam membangun agar keberlangsungan dan eksistensi Paud tersebut dapat tercapai sehingga layanan anak dapat terpenuhi. Dalam penyelenggaraan PAUD Terpadu tidak terlepas peran dari pada Masyarakat dan steakholder yang ada didaerah setempat.Peran serta masyarakat diwujudkan dalam bentuk kerja samadan dukungan antara lembaga PAUD, masyarakat dan pemerintah sehingga dapat memenuhi kebutuhan anak di usia PAUD secara optimal sehingga menjadikan generasi mendatang memiliki karekter yang mumpuni.

Kata kunci: PAUD (Pendidikan Anak Usia Dini), Terpadu
\end{abstract}

\section{A. Pendahuluan}

Dewasa ini perkembangan dunia pendidikan kita melalui program sentralistik dan desentralisasi mengalami perkembangan sangat pesat artinya kepedulian pemerintah begitu besar terhadap pendidikan, tidak terlepas dari sektor pendidikan anak usia dini. Oleh karenanya Undang-undang Nomor 20 Tahun 2003 tentang Sistem Pendidikan Nasional Pasal 1 angka 14 menyatakan bahwa Pendidi- 
kan Anak Usia Dini (PAUD) sebagai payung hukum adalah suatu upaya pembinaan yang ditujukan kepada anak sejak lahir sampai dengan usia enam tahun yang dilakukan melalui pemberian rangsangan pendidikan untuk membantu pertumbuhan dan perkembangan jasmani dan rohani agar anak memiliki kesiapan dalam memasuki pendidikan lebih lanjut. Dalam perkembangannya, masyarakat telah menunjukkan kepedulian terhadap masalah pendidikan, pengasuhan, dan perlindungan anak usia dini untuk usia 0 sampai dengan 6 tahun dengan berbagai jenis layanan sesuai dengan kondisi dan kemampuan yang ada, baik dalam jalur pendidikan formal maupun non formal. (UU SISDIKNAS No:20 Th 2003)

Upaya mewujudkan cita-cita tersebut di atas, diperlukan adanya peran serta semua pihak dalam peningkatan dan pengembangan layanan Pendidikan Anak Usia Dini. Pada tahun 2009 menunjukkan bahwa anak yang terlayani program Taman Kanak-Kanak (TK), Raudhatul Athfal (RA), Kelompok Bermain (KB), Taman Penitipan Anak (TPA) dan Satuan PAUD Sejenis baru mencapai 53.19\%. Hal ini berarti masih terdapat $46.81 \%$ anak belum terlayani program Pendidikan Anak Usia Dini. Berbagai strategi telah dilakukan untuk meningkatkan dukungan para pemangku kepentingan yaitu dengan membangun kerja sama dengan Organisasi Kelembagaan, Organisasi Profesi, Organisasi Keagamaan, Organisasi Wanita dan pihak lain yang memiliki komitmen terhadap pendidikan. (Sudibyo: 2012: 1)

Oleh sebab itu pembinaan Pendidikan Anak Usia Dini perlu dilaksanakan secara terpadu dan terkoordinasi, agar kemampuan anak dapat berkembang sesuai dengan usianya. Peraturan Menteri Pendidikan Nasional Nomor 36 Tahun 2010 tentang Organisasi dan Tata Kerja Kementerian Pendidikan Nasional menetapkan bahwa pembinaan pendidikan anak usia dini, baik yang mencakup PAUD Formal (TK/RA), PAUD Nonformal ( TPA, KB dan SPS), dan PAUD Informal, pembinaannya menjadi kewenangan Direktorat Jenderal Pendidikan Anak Usia Dini, Nonformal dan Informal, yang secara teknis dilakukan Direktorat Pembinaan Pendidikan Anak Usia Dini. Artinya tidak ada perbedaan lagi antara anak yang bersekolah di PAUD Formal (TK/RA) dengan PAUD non Formal dan PAUD Informal, sama-sama satu Dirjen yaitu Direktorat Pembinaan Pendidikan Anak Usia Dini. 


\section{$112 \frac{\text { Jurnal AL-AFKAR }}{\text { Vol. II, No. II, Oktober } 2013}$}

\section{B. Hakikat PAUD}

Paedagogos (pendidik atau ahli ahli didik) adalah seseorang yang tugasnya membimbing anak dalam pertumbuhannya agar dapat berdiri sendiri, sedangkan istiah Pendidikan berasal dari kata paedagogiek yang artinya ilmu pendidikan Pendidikan adalah usaha sadar yang dilakukan secara berkelanjutan. (Purwanto, 1995:3)

PAUD Menurut UU No. 20 Tahun 2003 tentang Sistem Pendidikan Nasional Bab 1, Pasal 1, Butir 14, yang menyatakan bahwa : "Pendidikan Anak Usia Dini adalah upaya pembinaan yang ditujukan kepada anak sejak lahir sampai dengan usia enam tahun yang dilakukan melalui pemberian rangsangan pendidikan untuk membantu pertumbuhan dan perkembanagan jasmani dan rohani agar anak memiliki kesiapan dalam memasuki pendidikan lebih lanjut". berikut ini ada pemahaman tentang Pendidikan Anak usia dini yakni:

1. Pendidikan anak usia dini (PAUD) adalah suatu upaya pembinaan yang ditujukan kepada anak sejak lahir sampai dengan usia enam tahun yang dilakukan melalui pemberian rangsangan pendidikan untuk membantu pertumbuhan dan perkembangan jasmani dan rohani agar anak memiliki kesiapan dalam memasuki pendidikan lebih lanjut.

2. Taman Kanak - Kanak (TK) adalah salah satu bentuk pendidikan anak usia dini jalur pendidikan formal yang memberikan layanan pendidikan bagi anak usia 4 - 6 tahun, untuk membantu pertumbuhan dan perkembangan anak, agar kelak siap memasuki pendidikan lebih lanjut.

3. Raudatul Athfal (RA) dan Bustanul Athfal (BA) adalah salah satu bentuk PAUD pada jalur Pendidikan Formal yang menyelenggarakan program pendidikan umum dan program keagamaan Islam bagi anak usia 4-6 tahun untuk membantu pertumbuhan dan perkembangan anak, agar kelak siap memasuki pendidikan lebih lanjut.

4. Kelompok Bermain (KB) adalah salah satu bentuk pendidikan anak usia dini jalur pendidikan nonformal yang memberikan layanan pendidikan bagi anak usia 2 - 4 tahun, untuk membantu pertumbuhan dan perkembangan anak, agar kelak siap memasuki pendidikan lebih lanjut. 
5. Taman Penitipan Anak (TPA) adalah layanan pendidikan yang dilaksanakan pemerintah dan masyarakat bagi anak usia lahir sampai dengan enam tahun sebagai pengganti keluarga untuk jangka waktu tertentu bagi anak yang orang tuanya bekerja.

6. Satuan PAUD Sejenis (SPS) adalah salah satu bentuk PAUD pada jalur pendidikan nonformal (PAUD Nonformal) yang dapat dilaksanakan secara terintegrasi dengan berbagai program layanan anak usia dini yang telah ada di masyarakat (seperti Pos PAUD, Bina Keluarga Balita, Taman Pendidikan Al-Qur'an, Taman Pendidikan Anak Soleh, Bina Iman Anak (BIA), Bina Anak Muslim Berbasis Masjid (BAMBIM), Sekolah Minggu, Pembinaan Anak Kristen (PAK), Pasraman, Vihara dan Sekolah Hindhu). Atau dengan kata lain Satuan PAUD Sejenis adalah salah satu bentuk layanan PAUD Nonformal selain dalam bentuk Taman Penitipan Anak dan Kelompok Bermain yang memberikan layanan pendidikan dalam rangka membantu pertumbuhan dan perkembangan anak, agar kelak siap memasuki pendidikan lebih lanjut.

7. Program PAUD Terpadu adalah program layanan pendidikan bagi anak usia dini yang menyelenggarakan lebih dari satu program PAUD (TK, KB, TPA, SPS) yang dalam pembinaan, penyelenggaraan dan pengelolaannya dilakukan secara terpadu atau terkoordinasi. ( UU No. 20 Tahun 2003 tentang Sistem Pendidikan Nasional Bab 1, Pasal 1, Butir 14).

Adapun tujuan pendidikan adalah untuk mengembangkan pengetahuan dan pemahaman orang tua dan guru serta pihak-pihak yang terkait dengan pendidikan dan perkembangan anak usia dini. Secara khusus tujuan yang ingin dicapai adalah: dapat mengidentifikasikan perkembangan fisiologis anak usia dini dan mengaplikasikan hasil identifikasi tersebut dalam pengembangan fisiologis yang bersangkutan, dapat memahami perkembangan kreatifitas anak usia dini dan usaha-usaha yang terkait dengan perkembangannya, dapat memahami kecerdasan jamak dan kaitannya dengan perkembangan anak usia dini, dapat memahami arti bermain bagi perkembangan anak usia dini, dapat memahami pendekatan pembelajaran dan aplikasinya bagi perkembangan anak kanak-kanak. Dalam ilmu psikologi, diketahui bahwa perkembangan anak manusia terdiri dari beberapa fase-fese perkembangan yang dilaluinya. Ada 3 fase dalam 


\section{$114 \frac{\text { Jurnal AL-AFKAR }}{\text { Vol. II, No. II, Oktober } 2013}$}

mendidik anak yang direkomendasikan, yaitu :

Fase ke-1

7 tahun pertama (Usia 0-7 tahun) perlakukan anak seperti raja karena fase ini fase penyerapan informasi yang sangat berguna.

Fase ke-2

7 tahun ke dua (usia 8-14 tahun) perlakukan anak seperti tawanan perang karena Fase ini merupakan penanamanan sikap dan disiplin.

Fase ke-3

7 tahun ke 3 (usia 15-21 tahun) perlakukan anak sebagai teman karena Fase ini anak membutuhkan tempat terbaik untuk menemukan dan membangun jai dirinya. (Fauzi:1999:79)

Sejalan dengan fase-fase di atas diperlukan kesinambungan pendidikan yang dalami anak, baik dalam keluarga maupun di sekolah, khususnya pada fase pertama usia 7 tahun pertama. Pada usia tersebut anak berada usia sekolah tingkatan PAUD yang bertujuan membentuk anak Indonesia yang berkualitas, yaitu anak yang tumbuh dan berkembang sesuai dengan tingkat perkembangannya, sehingga memiliki kesiapan yang optimal di dalam memasuki pendidikan dasar serta mengarungi kehidupan dimasa dewasa, membantu menyiapkan anak mencapai kesiapan belajar (akademik) di sekolah, intervensi dini dengan memberikan rangsanga sehingga dapat menumbuhkan potensi-potensi yang tersembunyi yaitu dimensi perkembangan anak (bahasa, itelektual, emosi, sosial, motorik, konsep diri, bakat dan minat), melakukan deteksi diri terhadap kemungkinan terjadinya gangguan dalam pertumbuhan dan perkembangan potensi-potensi yang dimiliki anak.

\section{Dasar Hukum PAUD Terpadu}

1. Undang-Undang Republik Indonesia Nomor 23 tahun 2002 tentang Perlindungan Anak.

2. Undang-Undang Republik Indonesia Nomor 20 tahun 2003 tentang Sistem Pendidikan Nasional

3. Peraturan Pemerintah Nomor 19 Tahun 2005 tentang Standar Pendidikan Nasional

4. Peraturan Pemerintah Nomor 48 Tahun 2008 tentang Pendanaan pendidikan 
5. Peraturan Pemerintah dan Nomor 17 Tahun 2010 tentang Pengelolaan dan Penyelenggaraan Pendidikan

7. Peraturan Menteri Pendidikan Nasional Nomor 58 Tahun 2009 tentang Standar Pendidikan Anak Usia Dini (PAUD)

8. Peraturan Menteri Pendidikan Nasional Nomor 36 tahun 2010 tentang Organisasi dan Tata Kerja Kementerian Pendidikan Nasional

9. Rencara Strategis (Renstra) Kementerian Pendidikan Nasional Tahun 2010-2014.

\section{Tujuan PAUD Terpadu}

\section{Tujuan Umum}

Memperluas dan meningkatkan akses dan mutu layanan PAUD bagi anak usia dini ( 0 - 6 tahun), melalui berbagai program PAUD (TK, KB, TPA, SPS) yang diselenggarakan secara terpadu dan terkoordinasi.

2. Tujuan Khusus

a. Meningkatkan akses layanan PAUD bagi anak usia 0 - 6 tahun, melalui berbagai layanan PAUD di lembaga PAUD Terpadu.

b. Meningkatkan tata kelola dan kapasitas lembaga PAUD dalam pengembangan, pembinaan dan penyelengaraan berbagai program layanan PAUD secara terpadu dan terkoordinasi.

c. Meningkatkan efisiensi dan efektifitas dalam perencanaan, pelaksanaan dan pengelolaan layanan PAUD (peserta didik, pendidik dan tenaga kependidikan, pembelajaran , sarana dan prasarana, pembiayaan dan pembinaan PAUD).

d. Target dan sasaran

Target/sasaran Program PAUD Terpadu adalah penyelenggara dan organisasi yang telah menyelenggarakan salah satu program layanan PAUD (TK/KB/TPA/SPS), dan selanjutnya ingin mengembangkan program layanan PAUD lainnya, misalnya TK Pembina/TK Swasta didirikan layanan KB,TPA dan Satuan PAUD Sejenis (SPS), demikian juga sebaliknya. (Kementrian Pendidikan dan Kebudayaan, 2012.4) 


\section{E. Prinsip Program PAUD Terpadu}

Penyelenggaraan PAUD Terpadu harus didasarkan pada prinsip-prinsip sebagai berikut :

1. Proses pembelajaran dilaksanakan dalam suasana yang menyenangkan bagi anak.

2. Proses pembelajaran dilaksanakan melalui bermain yang merangsang anak untuk aktif, kreatif, dan eksploratif.

3. Proses pembelajaran berfokus pada anak secara individu sesuai dengan minat, potensi, dan tahapan perkembangan yang dicapai.

4. Proses pembelajaran mendorong terjadinya interaksi di antara Anak dengan anak, anak dengan orang dewasa, dan anak dengan lingkungannya dalam suasana yang alami.

5. Proses pembelajaran membantu anak agar mandiri, berdisiplin, mampu bersosialisasi, dan memiliki keterampilan dasar yang mendukung perkembangan anak berikutnya.

6. Proses pembelajaran dilaksanakan secara bertahap, berulang, konsisten, konkrit dan tuntas sehingga memiliki kebermaknaan bagi anak.

7. Setiap Satuan PAUD wajib berupaya menampung anak-anak berkebutuhan khusus sebatas kapasitas yang dimiliki dengan tetap menjamin hak-hak anak yang bersangkutan untuk bergaul dengan sesama peserta didik secara wajar serta terlindungi dari perlakuan diskriminatif, baik dari peserta didik lain, pendidik, maupun orang dewasa lainnya.

8. Setiap satuan PAUD wajib memberikan layanan gizi dan kesehatan dasar kepada anak dan/atau mengintegrasikan layanan PAUD dengan layanan gizi dan kesehatan dasar yang diselenggarakan pihak lain.

9. Setiap satuan PAUD wajib menyelenggarakan penyuluhan bagi para orang tua dan keluarga tentang gizi dan praktek kesehatan yang baik.

10. Secara bergotong royong penyelenggaran satuan PAUD bersama orang tua dan masyarakat mengupayakan penyediaan makanan bergizi dan kebutuhan suplemen vitamin yang dibutuhkan anak. 


\section{F. Peranan Masyarakat/Publik Terhadap Eksistensi PAUD Terpadu}

Keberadaan PAUD terpadu merupakan sebuah jawaban permasalahan Pendidikan pada suatu komunitas daerah maka dibutuhkan kerja ekstra dalam membangun agar keberlangsungan dan eksistensi Paud tersebut dapat tercapai sehingga layanan anak telah terpenuhi. Selain itu penyelenggaraan PAUD Terpadu tidak terlepas peran dari pada Masyarakat dan steakholder yang ada didaerah setempat.Melalui dukungan masyarakat yang memadai terhadap penyelenggaraan pendidikan yang bermutu. Peran serta masyarakat diwujudkan dalam bentuk kerja sama antara lembaga PAUD, masyarakat dan pemerintah yang dibangun berdasarkan kebutuhan rill.

Pemberdayaan peran serta masyarakat dapat dilakukan antara lain melalui :

1. Identifikasi Potensi Masyarakat

a. Penggalian sumber dana

b. Menjadi narasumber kependidikan

c. Membantu pengadaan fasititas dan sarana prasarana

d. Membantu penyebaran informasi kegiatan PAUD Terpadu

2. Pihak yang berperan dalam lembaga PAUD Terpadu

Agar bentuk peran serta masyarakat dapat terorganisir secara baik dan berjalan efektif serta efisien, maka dilakukan koordinasi dengan pihak-pihak lain di bawah ini:

a. Gugus PAUD Terpadu

b. Komite Sekolah/PAUD

c. Orang tua

d. Organisasi mitra PAUD yaitu (Organisasi Kelembagaan, Organisasi Profesi,Organisasi Wanita, Organisasi Keagamaan, dan Organisasi lain yang memiliki kepedulian dengan PAUD)

e. Dunia Usaha dan Dunia Industri dalam rangka pendukungan dana

f. Akademisi dan Praktisi.

Identifikasi potensial yang ada di masyarakat serta pihak yang berkompeten dalam penyelenggaraan Paud harus adanya jaringan kordinasi yang mana ini berfungsi sebagai tonggak dan kekuatan suatu lembaga Pendidikan agar eksis dan bertahan selamanya ditengah masyarakat, dikarenakan suatu hal yang mustahil bagi sebuah 
$118 \frac{\text { Jurnal AL-AFKAR }}{\text { Vol. II, No. II, Oktober } 2013}$

lembaga PAUD dapat berkiprah ditengah masyarakat tanpa adanya hubungan kerjasama yang erat.

\section{G. Penutup}

Seiring dengan meningkatnya tuntutan dan kebutuhan masyarakat untuk memperoleh layanan pendidikan, termasuk Pendidikan Anak Usia Dini (PAUD), di seluruh pelosok Negeri maka kebijakan untuk pengembangan Program PAUD Terpadu sebagai jawaban, sangatlah strategis dalam rangka meningkatkan angka partisipasi anak usia dini yang memperoleh layanan PAUD. Oleh sebab itu berbagai upaya telah dan sedang dilakukan untuk memperluas akses layanan dan meningkatkan mutu layanan PAUD Terpadu baik yang mencakup pengelolaan pembelajaran, pengelolaan peserta didik dan pendidik serta tenaga kependidikan, pengelolaan pembiayaan, pengelolaan sarana prasarana serta membangun kerja sama kemitraan bersama Masyarakat.

Akhirnya melalui pengembangan Program PAUD Terpadu ini, diharapkan dapat memberikan dan mendorong peningkatan akses dan mutu layanan PAUD di Indonesia, yang pada gilirannya mampu melahirkan sumber daya manusia Inhil yang unggul, sehat, cerdas, ceria dan berakhlak mulia tentunya menjadikan anak dan generasi mendatang memiliki karekter yang mumpuni.

\section{Daftar Pustaka}

Fauzi, Ahmad, Psikologi Umum, Bandung, CV Pustaka setia, 1999 Muhammad, Hamid, Pedoman Pendidikan Anak Usia Dini Terpadu, Dirjen Pendidikan Anak Usia Dini Non Formal dan Informal, Jakarta, 2012

Sudjarwo, Pedoman Teknis Penyelenggaraan Kelompok Bermain, Direktur Pendidikan Anak Usia Dini, Jakarta, 2008

Sudibyo, Bambang, Peraturan Menteri Pendidikan Nasional Nomor 58 Tahun 2009 Standar Pendidikan Anak Usia Dini, Mentri Pendidikan Nasional, 2009

UU No. 20 Tahun 2003 tentang Sistem Pendidikan Nasional Bab 1, Pasal 1, Butir 14). Jakarta 
Purwanto, Ngalim, Ilmu pendidikan Teoritis Dan Praktis, Bandung, Remaja Rosda Karya, 1995

Purwanto, Ngalim, Psikologi Pendidikan, Bandung, Rosda Karya, 2004 